\title{
STATE-LEGAL REGULATION \\ OF SOCIO-ECONOMIC PROCESSES: FOREIGN EXPERIENCE AND UKRAINE
}

\section{Silenko A. A.}

\section{INTRODUCTION}

Social policy is a mechanism for implementing a social function. In political science, the functions of the state are defined as the main directions of its activity, determined by the main social goals and objectives at the concrete historical stage of its development. Thus, the functions of the state are formed in the process of its formation, strengthening and development.

The consolidation of the social principle of the state system in the legislation of many countries means that the state is called upon to serve society, and not vice versa. For example, in the Italian Constitution of 1947 enshrined: "The task of the Republic is to remove obstacles of an economic and social order that, limiting freedom and equality of citizens, impede the full development of the human personality and the real effective participation of all workers in the political, economic and social organization of the country".

The constitutional consolidation of the social principle of the state structure of Ukraine is confirmed by the fact that the social function belongs to priority functions. It should be noted that the content of the social function does not remain unchanged at all stages of the development of society and the state. It depends on many factors, primarily on the type of political regime, political ideology. In principle, the content of the social function indicates what and how the state does in the social sphere. So, for example, if the social policy of a modern democratic state with a high economic level of development is aimed at supporting public welfare, creating conditions for its achievement, then for a state experiencing a transition from one social system to another, another goal is relevant, namely, elimination or mitigation of negative social consequences caused by the sharp contradiction between the need for a tough economic policy and the social vulnerability of the population. Despite this, social policy is of particular importance, one of the tasks of which is the redistribution of income, reduce social tension. Thus, the priorities of social development in transition should be determined.

Activities to study social policy as a specific function of the state and society began during the laying of the foundations of the social state. At the end of the nineteenth century. a group of German scientists founded the 
"Circle of Social Policy", the aim of which was to study the development of politics and economics in the context of sociology. It is natural that this happened in Germany, where a conscious and focused policy was aimed at building such a state.

However, the concept of "social policy" was introduced into scientific circulation not in Germany, but in France - a vivid representative of utopian socialism, Charles Fourier. It is to him that we owe the fact that the question of the obligation of the state to provide its citizens with some social guarantees was raised on the agenda. And to make this possible, the state must monopolize trade, issue money and collect taxes. For S. Fourier, state monopoly was a social policy. We owe the Germans the fact that their state was the first to become interested in the social sphere of society, to take care of the German workers and their families. So for the first time a social security system was introduced, not only controlled by the state, but also managed by it.

\section{Representations of the social state in domestic and foreign science}

Since the end of the nineteenth century (1883), and with the decrees of O. Bismarck on state assistance to the families of German workers, specific state activity began on the social protection of wage workers.

In the future, the concept of social policy was considered in the context of ideas about the social state. Given the fact that the social state has several types, it is clear that social policy was interpreted differently by representatives of various areas of social thought. Shared by the authors is the claim that the modern State necessarily has to carry out social policies. And although the term "social state", as a rule, is applied to such European countries as Sweden, Germany, Denmark, etc., at the same time, it can be stated that any modern (modernized) state has certain signs of social state. Even in countries where strong traditions have socio-economic liberalism, for example in the United States, a targeted state policy is also being pursued.

Even thinkers of the past (Aristotle, T. Hobbes, Kant, G.V.F. Hegel and others) considered the question of the obligations of the state to its citizens, considering justice an undeniable social and moral value. So, V. von Humboldt in his work "Ideas for the experience that defines the boundaries of the state's activity" analyzes both the legal functions of the state (peace and security in society, protection of the rights and freedoms of the individual) and social (caring for the welfare and happiness of everyone). The concept of the maximum participation of the state in ensuring the social conditions of life of citizens is described in the work of I. Fichte, "Closed Trade Power".

State and legal regulation of socio-economic processes has become a characteristic feature of the development of most Western countries in the 
second half of the twentieth century, in which power acquired socio-economic legitimacy.

This experience is especially valuable for Ukraine, where society and the economy are in a very deep crisis, where there is a high degree of social inequality and at the same time there is no agreement between political forces on issues regarding the strategy of social development. To eliminate the causes of social injustice, as historical experience confirms, it is possible only through active state regulation, is a characteristic feature of the activity of a social, legal state.

The model of the social state during its existence was subjected to serious tests associated with the periodic deterioration of the economic situation. The concept of a social state has been criticized too sharply, and not without reason, for raising the priority of rights over duties, equalizing people's assessments of efforts, reducing incentives to achieve success, not understanding the role of private business in solving social problems reducing unemployment, creating additional jobs, improving quality social services and the like.

In foreign and domestic political science, the following main theoretical and methodological approaches to the problem of welfare states are described. Thus, liberal welfare states (USA) are distinguished, in which the provision of need is carried out on the basis of the residual principle; conservative corporatist welfare states (Germany), based on social insurance, and social democratic welfare states (Sweden), where income is redistributed due to the high level of taxation. Sweden has become a world leader in optimally meeting social needs. The Swedish welfare state was able to ensure full employment, significantly reduce class divisions, and achieve public agreement on the existence of a welfare state.

The feminist approach proposes to consider indicators of women's needs satisfaction as a criterion for assessing welfare states. In particular, the level of orientation of the policy on family welfare, the appropriateness of female labor (the ability of women to work on equal terms with men) and which of the parents receives help for children are highlighted.

According to another approach, an indicator such as the share of social security expenditures in the gross national product is used to analyze welfare states.

States are classified according to: the degree of intensity of political mobilization of the working class (that is, the degree of unification of the working class in trade unions and the average percentage of votes cast for social-democratic or other "left" parties); the frequency with which workingclass parties exercise control over the government (the degree and duration of 
participation in the government and the number of seats in parliament) the level of support for "right" parties.

This approach revealed countries in which the level of mobilization of the working class was higher and control by the "left" parties is quite stable (Sweden, Norway), and countries that were characterized by a high level of mobilization of the working class, but low (Australia) or irregular (UK) level of control.

The available data indicate that there is a relationship between the political orientation of the government and the level of expenditures for social purposes. At the same time, countries such as the Netherlands, West Germany and France had high rates of social spending in the early 1990s, but there was no high level of mobilization of the working class and the government was not controlled by the "left". Some researchers explain this phenomenon by the fact that in the political system of countries such as the Netherlands, Belgium, West Germany, Austria, Christian parties played the same role as the Social Democratic parties in the Scandinavian countries. So, if the "left" orientation of the government is not a prerequisite for a high level of social spending, then their low level is still due to the dominance of the "right" political forces.

Based on a different approach proposed in comparative political science by the Katwright-Wilensky school, the main reason for the development of the welfare state is the economic level, not ideology. Political factors also, according to these researchers, the impact likely to choose social programs implementation time, rather than on their content ${ }^{1}$.

I. Doyal and T. Thomas argued that economic development then better contributes to welfare when it is governed by effective authorities that guarantee civil, political and social rights for all ${ }^{2}$.

A comparative analysis of these models of developed welfare states allows us to conclude that they differ in the degree of influence of various political factors, sources of financing and means of organization, the impact on the benefits provided to citizens regarding women and ethnic minorities.

The classification of existing types of welfare states is not limited to the foregoing. For example, S. Jones proposed the concept of a Confucian model of a welfare state. In addition, the features of some countries do not yet make it possible to classify them. This applies to the countries of Southeast Asia, in which, on the one hand, active investment is made in social infrastructure, and on the other, welfare is seen as a burden and is associated with liberalism. As the main features of these states, the following can be distinguished:

\footnotetext{
${ }^{1}$ Wilensky H. (1975), Welfare State and Equality: Structural and Ideological Roots of Public Expenditures. Berkeley, p. 45, 47.

2 Политическая Наука: новые направления. (1999). М.: Вече, 815 с.
} 
a significant role of states in the centralized management of capital investments and their regulation; the willingness of the state to invest in social infrastructure related to job creation; high level of private savings; If there is a family that can provide support, social assistance is not provided.

Foreign scientists R. Darendorf, J. Rawls, E. Harms, F. Neumann, G. von Haferkamp, G.-G. made a great contribution to the development of the problems of the social state and the welfare state, as well as their institutions. Hartwig, V. Abendrot, K. Lenk, G. Brown, M. Niehaus, G. Ehrenberg, A. Fuchs, M. Speaker, G. Vilensky, C. Lebo, R. Titmus, A. Evers, I. Svetlik, P. Baldwin, J. Barnes, B. Wattenberg, C. Espin-Andersen, etc.

A. Hicks, J. Misra, Tang Nah Ng devoted their research to the political factors of the formation of the welfare state. The influence of socio-economic development on the political system has been the subject of research by such well-known scientists as D. Easton, H. Linz, M. Dogan, S. Lipset and others.

Among domestic researchers, the scientific works of V. Babkin, G. Shchedrova, A. Skripnyuk, V. Selivanov, N. Khoma and others should be highlighted.

Starting in the 90s of the last century, the countries of Central and Eastern Europe tried to make a sharp leap into unregulated pluralistic democratically liberal capitalism. However, none of these countries escaped the economic downturn and negatively affected subsequent development. Liberal policies have led to a drop in production levels, an increase in income inequality, high unemployment, a drop in living standards, and a significant increase in mortality in most of these countries.

\section{The social state in Ukraine}

After the collapse of the Soviet Union and the creation of independent states on its territory, Ukraine faced the problem of determining the path for further political and social development. In the field of social policy, the question of which social security system will replace the collectivist statebureaucratic system has become particularly relevant.

It was assumed that market mechanisms and institutions, which in the Western countries have passed the centuries-old development path, can be created in post-communist states in a very short time. At the same time, the focus of the governments of countries with economies in transition was turned to legal and political institutional reforms, and social policy issues, as expected, would be resolved by themselves. As a result of this approach, the old social security system collapsed, but the new one was not created.

Millions of people were left alone with the market element. Most countries with significant external debt were forced to accept the liberal version of the development of the socioeconomic sphere, which was facilitated by 
international organizations such as the International Monetary Fund, the World Bank, etc. The liberal reforms in Ukraine led to serious social consequences. The number of suicides, murders, and other manifestations of deviant behavior has sharply increased, and indicators of the state of health of the population have worsened.

And if at the very beginning of transformations liberal politics in society was received favorably and with hope, then, experiencing discomfort in the conditions of "wild" capitalism, the population of Ukraine again demanded the stability of social security, justice, and equality.

The existing today in Ukraine, the socio-political situation proves that the consolidation of the society and its withdrawal from the deep crisis is possible only on the basis of policy, aimed at building a democratic and social state of law. As world experience confirms, the transition from one socio-political system to another is always accompanied by a decline in the standard of living of the population, which can lead to increased instability. Therefore, such issues as assessing the role of the state, its participation in the socio-economic sphere, forms and methods of state regulation of the way of forming the foundations of sustainable development of the state and society are of particular importance.

These are problems in the solution of which are interested both new social groups that have arisen as a result of the introduction of market relations, and those that need state support.

It is possible to solve these problems only on the basis of a new social reform strategy; it is reflected in the concept of a social, legal state. It provides all citizens with guarantees of the rights to self-realization, social protection, and the strengthening of social partnership between the state, employers and trade unions.

A reduction in the number of poor, a narrowing of the gap between wealth and poverty through flexible state regulation, redistribution of resources through progressive taxation, and a solid social security system contribute to increased stability and reduce the possibility of social and political disasters.

Unfortunately, the functions of the social state in Ukraine are declining. This is indicated by a number of facts. For several years, Ukrainians have been paying housing and communal services at European prices, while the salaries of Ukrainians are significantly behind European. Subsidies to compensate for utility bills can be called very effective as an effective means of helping the population. Firstly, a part of those working in the private sector and receiving salaries in envelopes, without actually needing such assistance, are legally subsidies.

Secondly, as you know, only people working for the state, the so-called state employees, honestly pay taxes. However, with a small salary, they do not 
meet the criteria for subsidies. Thus, on the one hand, they pay utility bills at full cost, on the other hand, through their taxes they pay subsidies to others, including those who do not really need them.

Ukraine has become a country with labor poverty when working people are not able to pay for utilities and other vital services and goods. The average salary in Ukraine in November 2019 was $10679 \mathrm{UAH}^{3}$. 70\% of Ukrainians are poor people who receive subsidies, because they are not able to pay for utilities, which, according to the National Academy of Sciences of Ukraine, $30 \%$ of the required rate are malnourished, $38 \%$ milk products, $22 \%$ eggs $^{4}$.

Of particular note is the draft new labor code, which is planned to replace the Labor Code. Bill on Labor (No. 278). Thanks to the new law, the employer will have the opportunity to dismiss employees during vacation or sick leave. Pregnant women, women on maternity leave, invalids and ATO veterans are deprived of protection from the employer. The new labor code introduces ambiguity in the issue of sick leave payment in case of employee incapacity for work. Currently, the sick-list is provided by the social protection system, thanks to which the employee receives a fixed percentage of income. As political political expert Mikhail Chaplyga rightly believes, "When the role of the state is removed from labor relations, the worker becomes a slave and the employer becomes a slave owner. For this reason, the employer and the employee will never be able to negotiate on equal terms"

The rejection of paper work books is a lot of questions. As is known, with $2000 \mathrm{~g}$ of. in Ukraine, information on seniority is recorded in electronic registers. However, no one explains how the experience earned before 2000 will be taken into account.

When it comes to salaries, pensions and other social benefits for the population, the Ukrainian government, regardless of its ideological orientation, is extremely stingy with measures that improve the life of the population. We have to admit that all the economic reforms that the authorities carried out for 29 years in Ukraine have failed. And, today, without material support from international financial organizations, Ukraine cannot exist. The stratification by income level between rich and poor is growing, as evidenced by the dynamics of changes in the structure of expenditures. "95\% is spent on current expenses, and it was $83 \%$. And part of the expenses is financed from previous accumulations.

\footnotetext{
${ }^{3}$ Средняя зарплата в Украине URL: https://index.minfin.com.ua/labour/salary/average/

4 Бортник: Украина уже не является социальным государством URL: https://uiamp.org.ua/bortnik-ukraina-uzhe-ne-yavlyaetsya-socialnym-gosudarstvom-0

${ }_{5}^{5}$ Что изменят в новом трудовом кодексе: забастовки, выплаты, наказание за буллинг. URL: https://24tv.ua/ru/trudovoj_kodeks_ukrainy_2020_izmenenija_novyj_trudovoj_kodeks_ n1218242
} 
That is, income from assets will decrease in the future - the population takes this money and spends on consumption. Each of the income gap between rich and poor Ukrainians becomes a year wider ${ }^{6}$.

As noted by Ruslan Bortnik, " $70 \%$ (according to other estimates $-60 \%$ ) of Ukrainians - the poor, and, say, the top 10 of the Forbes list increased their bogats va on. $40 \%$ of social stratification in our gains is absolutely inadequate and cynical forms and it will continue, because in. Tools initiation increase the value of housing services and in other ways the richest continue to get richer and the poor will grow poor"

At the same time, the political and state elite continues to grow rich not thanks to innovative projects, but to proximity to the state budget, which they use for their own commercial purposes. With business capacity- with the state manifested by the fact that the owners are trying, often very successfully, click on the process of public decision-making.

At the same time, it is known that many officials of the state apparatus are actively involved in entrepreneurial activity. The merging of business with the state is the reason for the emergence of unequal sectors of the economy privileged and unprivileged. The first, receiving various benefits from the state, operates in "greenhouse" conditions that have nothing to do with the conditions of a market economy, and thereby put pressure on the unprivileged sector of the economy. The result of this economic policy of the state can be considered the absence of conditions for foreign capital, accustomed to work in other conditions where all participants in market competition are equal. The presence of a twosector economy is the cause of the polarization of the business elite.

It should be noted that a market economy is social in its principles. It subordinates its development to the interests and needs of the individual, creates the conditions for the realization of his abilities, encourages industriousness, initiative, drives incentives for highly productive and efficient work. However, at the previous stage of development of the Ukrainian economy, the implementation of this principle was practically impossible. The lack of appropriate state mechanisms, corruption at different levels of government led to excessive property stratification of the population. Such stratification, which undermines social and political stability, occurs spontaneously, mainly on a shadow basis.

$\mathrm{C}$ otsialnaya policy is a factor of political stability, one of the main prerequisites for a sustainable society state that can effectively work under

6 В Украине растет пропасть между богатыми и бедными - эксперты URL: https://www.segodnya.ua/economics/enews/v-ukraine-rastet-propast-mezhdu-bogatymi-i-bednymieksperty-1300010.html

${ }^{7}$ Бортник: Украина уже не является социальным государством. URL: https://uiamp.org.ua/ bortnik-ukraina-uzhe-ne-yavlyaetsya-socialnym-gosudarstvom-0 
various influences, while maintaining their structure and ability kontrolirova be a process of social change. At the same time, it is known that economic crises, a decline in production, a deterioration in the standard of living of the population, pronounced imbalances in the distribution of incomes often led to the destruction of the political system. Thus, the task of social policy is to create conditions for improving the standard of living of the population, which should feel its personal interest in the peaceful and conflict-free development of society. Citizens should know that the most important institutions of the state and society are able to adequately and timely respond to their needs.

Ideally, social democracy, which relies on solidarity and joint action, could become the vehicle for such a policy. As one of the leaders of the SPD, O. Lafontaine, noted, the Social Democrats "realized that humanity will survive only if it finds a path to joint action... Any concept that aims at a free society of the future must be accepted by the universal principle of solidarity". It was the Social Democrats in the post-war decades that carried out successful socio-economic reforms and became the basis for the next rapid economic development of industrial countries.

Today's Social Democrats are significantly different from the Social Democrats of the 70s. In particular, they revised their positions on individual freedom, private property, market relations and related values and attitudes. The programs of modern social democratic parties mark the tandem of private capitalist market principles of economics and regulation of the economy (Keynesian approach), and assistance to the needy sectors of society, a high level of employment.

According to modern approaches, the essence of the transformation of a social state lies in its new, more active role in the process of adaptation of an individual to the conditions of his life; they have changed, which will allow him to successfully "get involved" in society. The main goal of a changing social state - to achieve a high degree of social inclusion - opens up wide opportunities for social development and helps to transform the social state into a "state of social investment". This means the emergence of a new function of the social state - the promotion of initiative, creativity and readiness for "new challenges". Thanks to this, according to the current Social Democrats, society can enter a "new era of manageability" and contribute to the creation of an "information society" or a knowledge-based society.

For the implementation of the social democratic model in Ukraine, certain prerequisites are necessary: economic growth; harmony and consolidation of society around fundamental values; strengthening social partnership between the state, trade unions, employers and other public groups; strengthening the social orientation of reforms; determination of the real parameters of social policy, especially in the areas of income, employment and social security. 
They need to be created if our country chooses a policy aimed at building a democratic, socially just society.

The thesis that a legal state of a liberal type as a form of organization and activity of state power has exhausted itself is also confirmed by the experience of Western countries. Undoubtedly, negative rights need to be supplemented by positive rights, which provide for the organizing and regulatory function of the state. Thus, the question on the transformation of the legal state of the liberal type into a legal social state was raised on the agenda. As the wellknown Ukrainian scientists V. Babkin and V. Selivanov rightly note, the social state "is based on the principle of maintaining a certain balance between democratic institutions and strong state power, planning and the market, private and state property, economic efficiency and social justice"

Social changes are an inevitable attribute of the development of societies and the progress of civilization. Another question: what are their messages to people? Consideration of the principles of the activity of the social state allows us to conclude that the evolution of the social state is positive, which has passed from the statist type to a mixed public-private form, which has significantly increased the effectiveness of the modern social state. This led to changes in its structure, elements of which, along with the state itself, are private business and non-profit public organizations, which are otherwise called the "third sector". The "third sector" was in the center of public and political attention due to the fact that the state and the market in the social sphere are limited. According to Ukrainian researcher H. Homa, "national model of social th sudarstva should be based on the console datsiyu efforts of the three components of society - government, business and the public: for the mouth ment of partnerships between government and business, intensification of the dialogue between the state and society. Effectiveness tive interaction Social Party ers, to achieve an optimal balance and the distribution of responsibilities between the state, business and general stvom should accelerate the development"'

An objective analysis shows that the establishment of a social state in our country is still a matter of the future.

The path to a social state is complicated by the fact that we have to simultaneously create a reliable foundation for a future social state and at the same time solve urgent current problems of the transition period, associated, for example, with the search for new models of social protection for a significant part of the Ukrainian population. The existing system of social

\footnotetext{
${ }^{8}$ Бабкін В.Д. (2001) Від правової до соціально-правової держави. Правова держава: Щорічник наук. пр., вип. 12, с. 276.

9 Хома, Н.М. (2013). Особенности модели социального государства в Украине. Среднерусский вестник общественных наук, № 1, с. 155.
} 
protection needs to be reviewed, because its mechanisms are not able to solve the problems of material support for those who need help. Therefore, the main characteristics of the new models of social protection should be both social efficiency and economic.

\section{CONCLUSIONS}

Based on the foregoing, we formulate the main functions of the modern social state: state and legal regulation of the economy; redistribution of income; protective function: in its broadest sense - protecting society from schism and upheaval, supporting the social world; in the narrow, protection of the population in a market economy; combating poverty, reducing social inequality; fight against crime; security and regulatory, providing for the responsibility of business to the state and third parties.

It is clear that a market economy better than any other system satisfies people's needs. At the same time, as world practice shows, market relations are primarily focused on the laws of profit and cost accounting. And this means that decisions in the economic sphere are made taking into account narrow commercial interests, and not from the standpoint of social responsibility. Therefore, in order to protect itself, society needs the regulatory function of the state, the legal social state.

The success of social development is possible only if a reasonable definition of its real goals. While in our country there is no clear idea of the society we are striving for. The state has not decided on a citizen in the conditions of transition to market relations. Thus, the most important problem associated with determining the nature of the relationship in the system of "state - man" has been solved.

It should be noted that the scientific study of the essence, functions, and the formation of the social state in Ukraine has been going on for a long time. However, researchers still face many challenges that require new approaches. Among them - the definition of the boundaries of state intervention in the socio-economic sphere; elimination of sharp disagreements of the material statuses of individuals; consequences of managerial decisions in the field of social policy for the population; the dependence of the degree of increase in social expenditures on the level of professionalism in the legislative and executive authorities and many other problems, the development of which will create a theoretical basis for the practical implementation of the principles of the social state in Ukraine.

\section{SUMMARY}

The article considers the issue of state legal regulation of socio-economic processes. The main theoretical and methodological approaches to the study of the problems of the social state are analyzed. It is argued that the functions 
of the social state in Ukraine are declining. It is shown that the consolidation of Ukrainian society and its withdrawal from a deep crisis is possible only on the basis of policies aimed at building a democratic, social, legal state.

\section{REFERENCES}

1. Бабкін В.Д. (2001) Від правової до соціально-правової держави. Правова держава: Щорічник наук. пр., вип. 12, с. 270-281.

2. Бортник: Украина уже не является социальным государством URL: https://uiamp.org.ua/bortnik-ukraina-uzhe-ne-yavlyaetsya-socialnymgosudarstvom-0

3. В Украине растет пропасть между богатыми и бедными эксперты URL: https://www.segodnya.ua/economics/enews/v-ukraine-rastetpropast-mezhdu-bogatymi-i-bednymi-eksperty-1300010.html

4. Политическая Наука: новые направления. (1999). М. : Вече, 815 с.

5. Средняя зарплата в Украине. URL: https://index.minfin.com.ua/ labour/salary/average/

6. Хома, Н.М. (2013). Особенности модели социального государства в Украине. Среднерусский вестник общественных наук, № 1, с. 153-158.

7. Что изменят в новом трудовом кодексе: забастовки, выплаты, наказание за буллинг URL: https://24tv.ua/ru/trudovoj_kodeks_ukrainy_ 2020_izmenenija_novyj_trudovoj_kodeks_n1218242

8. Wilensky H. (1975), Welfare State and Equality: Structural and Ideological Roots of Public Expenditures. Berkeley, 151 p.

\section{Information about the author:}

Silenko A. A.,

Doctor of Political Sciences, Professor, Vice-Rector, Odessa National Academy communication of A. S. Popov 1, Cuznechna str., Odessa, 65000, Ukraine 